\title{
Ionel Apostolatu, Analogia - factor de organizare lexico-gramaticală. Cu privire la limba română, Casa Cărții de Știință, Cluj-Napoca, 2013, 389 p.
}

\author{
Adrian Chircu* \\ Facultatea de Litere, Universitatea „Babeș-Bolyai”, Str. Horea 31, 400202 Cluj-Napoca, România
}

Cartea pe care Ionel Apostolatu a publicat-o la una dintre editurile clujene reprezentative era de mult timp aşteptată de către lingviştii români, deoarece aceştia se ghidau, în general, în interpretarea faptelor de limbă analogice, după lucrări teoretice mai vechi, apărute în străinătate, care nu dădeau prea mult seamă de limba română şi de specificul acesteia.

Fără îndoială, trebuie să recunoaştem, dintru început, că subiectul ales (lucrarea reprezintă o variantă prelucrată a tezei de doctorat, susținută la Universitatea "Alexandru Ioan Cuza” din Iaşi, sub îndrumarea Prof. univ. dr. Stelian Dumistrăcel) nu a fost uşor de gestionat, mai ales că implicarea specialiştilor români în lămurirea unor aspecte legate de analogie nu a fost întotdeauna constantă, suficientă şi eficientă.

Valorificînd, prin urmare, ideile vehiculate în studii de lingvistică teoretică, Ionel Apostolatu reuşeşte să ne ofere un studiu amplu, închegat şi bine ancorat în realitățile limbii române. De altfel, acesta ne avertizează, chiar în Cuvîntul-înainte, că îşi propune să abordeze analogia, într-o dublă perspectivă: „pe de o parte, una teoretică, de clarificare şi de sistematizare a conceptului şi a termenului de analogie, luînd în discuție diferitele accepții care is-au dat de-a lungul timpului in literatura de specialitate, cu toate controversele care au insoțit diversele interpretări ale acestui fenomen, iar, pe de altă parte, una demonstrativanalitică, de evidențiere a modului de funcționare efectivă a analogiei in limba privită ca proces, cu aplicație asupra materialului limbii române" (p.9).

Cuvîntul-înainte (p. 9-16) are rolul de a limpezi unele temeri privitoare la analogie, anticipînd liniile directoare ale studiului şi oferindu-ne multiple repere investigative, inclusiv bibliografice. Cercetarea întreprinsă se înscrie pe direcția studiilor sintetice, care dau seamă de numeroase fapte de limbă mai greu de înţeles, în care sînt antrenate nu numai perspectivele diacronică şi sincronică, ci şi ştiinţa autorului de a selecta fapte de limbă elocvente.

Încă din primele pagini ale celui dintîi capitol (17-141), Ionel Apostolatu dovedeşte că stăpîneşte în profunzime subiectul tratat, iar incursiunile în istoria ideilor lingvistice îl ajută să-şi lămurească anumite aspecte referitoare la cadrul teoretic. Am remarcat, de altfel, şi numărul mare de cunoştinţe de lingvistică generală şi de filozofia limbajului, care ajută la înțelegerea temei abordate. În viziunea autorului, fundamentele analogiei ar trebui căutate în Antichitate (Platon, Heraclit, Varro etc.) şi în epocile ori curentele culturale ce vor urma, dintre care se detaşează iluminismul (Rousseau, Diderot, Du Marsais, Smith etc.) şi (post)romantismul (Grimm, Bopp, Curtius, Osthoff, Brugman).

La aceste prime surse, se adaugă cele moderne din secolul al XX-lea (Vendryes, Martinet, Coşeriu etc.). În demersul său, Ionel Apostolatu nu se mulțumeşte doar să prezinte teoriile predecesorilor, ci încearcă să le critice ori să le asimileze, cu scopul vădit de a-şi construi un sistem care să-l ajute să analizeze pertinent fapte de limbă româneşti, care, după cum s-a precizat de nenumărate ori, s-au situat ori se situează sub semnul analogiei.

Toate aceste incursiuni bibliografice preliminare i-au permis să circumscrie cît mai bine fenomenul investigat şi să se oprească, la finele capitolului, asupra contribuțiilor româneşti la teoretizarea ori la explicarea unor fapte de limbă, pe baza analogiei (3.2. Scurtă privire asupra receptării conceptului de «analogie» in lingvistica românească şi importanța acordată fenomenului în literatura de specialitate), prin care încearcă să surprindă modul în care învăţaţii din veacul al XIX-lea înțeleg, explică şi aplică analogia în lingvistică. Chiar dacă primele ocurențe ale termenului analogie, la noi, nu sînt atestate în lucrări cu caracter lingvistic (matematică, filozofie, logică, pedagogie), autorul întrevede totuşi care sînt accepțiunile aces-

*Adresă de corespondență: adrianchircu@yahoo.fr. 
tuia.

Parcurgerea lucrărilor româneşti de gramatică din veacul paşoptist îi permit lingvistului gălățean să afirme că, „cu sensul tehnic din lingvistică, termenul analogie se întîlneşte pentru prima oară în literatura românească de specialitate la August Treboniu Laurian, în al său Tentamen Criticum, cea mai subiectivă gramatică a limbii române, contaminată de etimologism, în care se incearcă o reconstrucție ideală a limbii române, în forma considerată pură de către autor..." (p. 118).

Lui Treboniu Laurian îi vor urma şi alți lingvişti şi filologi (Timotei Cipariu, Aron Pumnul, Bogdan Petriceicu-Hasdeu, Lambrior, Lazăr Şăineanu, Philippide, Sextil Puşcariu, Al. Graur), care au făcut apel la analogie, pentru a justifica o anumită formă ori regularizare în sistem, toți amintiți cu temeinicele lor contribuții de către Ionel Apostolatu, care încheie primul capitol prin a afirma că „lingviştii români sau dovedit destul de ataşați de problema analogiei si, fară a cădea în vreuna din atitudinile extremiste care s-au manifestat în lingvistica europeană din secolul al XIX-lea si chiar de mai tîrziu, cu privire la efectele acestui fenomen, mulți dintre ei au apreciat-o la justa ei valoare, rezervîndu-i un loc important în procesul de formare si sistematizare a limbii, ca si în ansamblul manifestärilor lingvistice creatoare ale indivizilor vorbitori" (p. 141).

În cel de-al doilea capitol (Mecanismul analogiei şimanifestările ei în diversele compartimente ale limbii române), este atent observat modul în care analogia („o formă analogică reprezintă, aşadar, o formă (re)făcută după modelul uneia sau mai multor forme, conform unei reguli determinate”) funcționează în cadrul sistemului limbii române, insistîndu-se, în special, asupra efectelor acesteia, în diferitele compartimente ale limbii: fonetic (forma mîne cu $i$ analogic, de la plural, mîine); morfologic (soră - surori, prin analogie pluralul sore 'infirmiere'); lexical (după substantive de tipul crîşmăriţă, morăriţă s-au format bancheriță, barmaniță etc.).

Tot în acest capitol, sînt avute în vedere şi aspecte de ordin normativ, atent discutate, pe baza Doom 2 , care au rolul de a evidenția relația care se stabileşte între norma lingvistică şi analogie, cea care intervine „în formularea unor reguli în baza cărora funcționează principiile ortografiei limbii române actuale” (p. 170).

A treia parte a studiului (Analogia - mecanismul de forță al creativității lexicale) este dedicată exclu- siv vocabularului limbii române, compartimentul cel mai dinamic al limbii, unde apar inovații multiple, pe baza analogiei. Probabil că, în româna contemporană, acesta este singurul compartiment în care analogia guvernează aproape exclusiv şi în care abaterile şi creațiile alternează unele cu celelalte (vezi subcapitolul 2. Analogia lexicală - între abatere şi creație lingvistică). În sprijnul ipotezei sale, sînt aduse în discuție fapte de limbă actuale (în special, diferitele tipuri derivative, dintre care menționăm răspîndirea şi funcționarea sufixului -(i)adă: baroniadă, dosariadă, mizeriadă etc.), care justifică opțiunea autorului pentru discuțiile abordate în acest capitol.

În cel de-al IV-lea capitol (Analogia - factor de regularizare gramaticală), Ionel Apostolatu urmăreşte, diacronic şi sincronic, modul în care a funcționat, în limba română, analogia de-a lungul vremii (de la latină la română, în limba română veche şi în epoca modernă) şi ce repercusiuni a avut aceasta în stabilizarea sistemului gramatical (nominal ori verbal).

Cauzele „reaşezării” flexiunilor nominale şi verbale au fost determinate de „actiunea a trei categorii de factori: transformările fonetice, analogia şi tendința trecerii de la formele sintetice la cele analitice" (p. 228). Chiar dacă majoritatea aspectelor investigate (de pildă, reducerea declinărilor-p. 235242; simplificarea ori inovațiile din sistemul verbalp. 256-288) au mai fost interpretate din diferite perspective, în paginile lucrărilor de specialitate, autorul are meritul de a le fi pus într-o altă lumină, care să-1 ajute să observe fenomenul analogiei şi să-şi construiască adecvat teoria lingvistică aleasă.

Ultimul capitol, al V-lea (Manifestări nesistematice ale analogiei), este dedicat analizei unor fenomene strîns legate de funcționarea analogiei în cadrul sistemului, precum contaminația, hipercorectitudinea şi etimologia populară, toate reprezentînd, inițial, devieri de la sistemul limbii, însă care se manifestă pregnant în epoci diferite sau în situații diferite, un rol important avîndu-l, fără îndoială, vorbitorul, cel care, din diferite rațiuni, face apel (conştient sau nu) la fenomenele amintite. Şi în acest ultim capitol, am observat o teoretizare cumpătată şi o selectare obiectivă a exemplelor, ceea ce asigură o lectură plăcută şi o asimilare rapidă a informației.

În succintele Concluzii, autorul sintetizează aspectele discutate şi relevă punctele forte ale lucrării, care vor reprezenta, cu certitudine, repere în descrierea faptelor de limbă de ieri şi de astăzi. Am avut 
în fața noastră o carte plină de învăţăminte lingvistice, uşor de citit, cu exemple clare, care se rețin cu uşurinţă. Detalierile autorului au fost lămuritoare, iar argumentarea, sobră şi doctă. Am remarcat, în permanență, dorința autorului de a acoperi toate aspectele şi de a profita din plin de ideile răspîndite în bibliografia de specialitate.

Sîntem convinşi că studiul lingvistului gălățean nu va rămîne fără ecou în interpretarea faptelor de limbă şi că avem de-a face cu un filolog matur, care ştie să filtreze informația asimilată şi, atunci cînd e necesar, să o analizeze cu un ochi critic. Cartea este, fără îndoială, una valoroasă şi va deschide noi căi de cercetare în domeniul lingvisticii teoretice ori în cel al lingvisticii aplicate. 